\title{
Role of cytokines in the pathogenesis of the euthyroid sick syndrome
}

\author{
Luigi Bartalena, Fausto Bogazzi, Sandra Brogioni, Lucia Grasso and Enio Martino \\ Dipartimento di Endocrinologia e Metabolismo, Ortopedia e Traumatologia, Medicina del Lavoro, University of Pisa, Pisa, Italy
}

(Correspondence should be addressed to L Bartalena, Dipartimento di Endocrinologia e Metabolismo, Ortopedia e Traumatologia, Medicina del Lavoro, University of Pisa, Via Paradisa, 2, 56124 Pisa, Italy)

\section{Introduction}

Nonthyroidal illness (NTI) is associated with complex changes in thyroid function tests and thyroid regulation known as the euthyroid sick syndrome (ESS) (1). The most common abnormality is a reduction in serum total triiodothyronine $\left(\mathrm{TT}_{3}\right)$ and, to a lesser extent, free $\mathrm{T}_{3}$ $\left(\mathrm{FT}_{3}\right)$ concentrations (2). Kinetic studies showed that the daily production rate $(\mathrm{PR})$ of $\mathrm{T}_{3}$ is decreased, while its clearance is unchanged in NTI (3). The reduction in serum $\mathrm{TT}_{3}$ concentration is usually accompanied by an increase in serum reverse $\mathrm{T}_{3}\left(\mathrm{rT}_{3}\right)$ concentration (1), although the latter is normal in patients with chronic renal failure (4), AIDS (5), or traumatic brain injury (6). $\mathrm{PR}$ of $\mathrm{rT}_{3}$ is unchanged, but its clearance is reduced (3). These changes in serum $\mathrm{TT}_{3}$ and $\mathrm{rT}_{3}$ concentrations are related to inhibition of the activity of type I $5^{\prime}$-deiodinase $\left(5^{\prime}-\mathrm{DI}\right)$, the enzyme catalyzing deiodination of thyroxine $\left(\mathrm{T}_{4}\right)$ to $\mathrm{T}_{3}$ and of $\mathrm{rT}_{3}$ to 3,3'-diiodothyronine (7). Serum thyrotropin (TSH) concentration is usually normal, although suppressed values may be found in a minority of patients (1). In addition, a decrease in the nocturnal surge of TSH has been consistently reported in patients with NTI (8-12). Abnormalities of TSH glycosylation causing its decreased biological activity were also described (13). The decrease in serum TSH secretion is in some instances related to the use of dopamine and glucocorticoids in critically ill patients (14).

The pathogenesis of changes in serum thyroid hormone and TSH concentrations leading to ESS is not completely understood. Reduced $\mathrm{T}_{3}$ generation in peripheral tissue may be related not only to a decreased $5^{\prime}$-DI activity, but also to decreased $\mathrm{T}_{4}$ transport into tissues (15). Substances, such as 3-carboxy-4-methyl-5propyl-2-furanpropanoic acid (CMPF) and indoxylsulfate, which are increased in chronic renal failure, and bilirubin and free fatty acids (FFA), which are increased in other NTI, were reported to decrease $\mathrm{T}_{4}$ uptake in rat liver tissue $(16,17)$. Interestingly, CMPF and indoxyl-sulfate did not affect TSH secretion in cultured rat anterior pituitary cells (18).

Recently, particular attention was focused on the role of cytokines in the pathogenesis of ESS. Cytokines are multifunctional molecules with different biological effects and target cells, which can exert autocrine (on the same cells that secrete them) and paracrine (on adjacent cells), but also endocrine (on distant cells) actions (19). They are usually produced in response to inflammation, infections and cellular injury, and their physiological role remains to be clarified (19). In general, cytokines act through binding to specific cellsurface receptors that were demonstrated also in thyrocytes $(20,21)$. In addition, thyrocytes synthesize and release cytokines, which might be involved in autocrine or paracrine regulation of thyroid function (22-32). The importance of cytokines in thyroid pathophysiology was recently underscored (Fig. 1). They participate in the pathogenesis of thyroid autoimmune disease by contributing to the growth and differentiation of $\mathrm{B}$ and T cells, by inducing expression of HLA class II antigens and adhesion molecules, by recruiting and activating immune cells and by modulating the course of the disease (33). Interleukin-6 (IL-6) and possibly other cytokines are useful markers of thyroid-destructive processes (34). Cytokines have a role in the pathogenesis of Graves' ophthalmopathy, since they induce orbital fibroblast proliferation and glycosaminoglycan production, and expression of HLA class II antigens, adhesion molecules and heat shock proteins in orbital fibroblasts (35). Numerous studies in vitro and in vivo (both in animals and humans) were carried out in recent years on the effects of cytokines on thyroid function. Since the number of published papers on this issue is very large, in this review we analyzed the most crucial studies to discuss the role of cytokines in the pathogenesis of ESS.

\section{Effects of cytokines on thyroid function in vitro}

Several effects of cytokines that might be relevant in the pathogenesis of ESS were demonstrated in in vitro systems (Table 1$)$. Tumor necrosis factor- $\alpha$ (TNF- $\alpha$ ) had no effect on iodide uptake under basal conditions in FRTL-5 cells (21), but it reduced TSH-stimulated iodide uptake in the same cell system $(21,36)$, as well as in four thyroid cancer cell lines (21). This action appeared not to be related to inhibition of TSH binding to its receptor or to be mediated by the phospholipase 


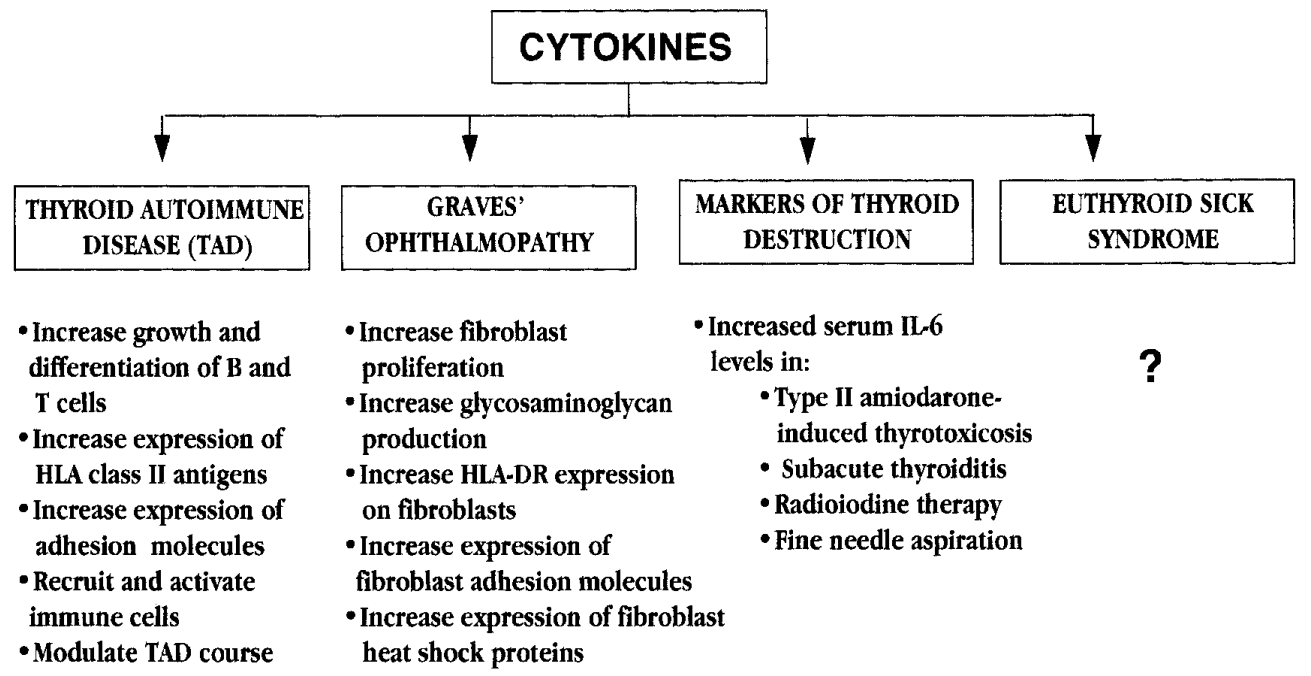

Figure 1 Involvement of cytokines in thyroid pathophysiology.

$\mathrm{A}_{2}$-arachidonic acid pathway or by $\mathrm{H}_{2} \mathrm{O}_{2}$, since inhibitors of the phospholipase $\mathrm{A}_{2}$-arachidonic acid pathway (promethacin, indomethacin) or the $\mathrm{H}_{2} \mathrm{O}_{2}$ scavenger, catalase, did not block the TNF- $\alpha$ effect (37). Likewise, IL-1 decreased both basal and TSHstimulated iodide uptake in FRTL-5 cells (37). Less clear results were obtained using a porcine thyroid cell system, in which IL- $1 \alpha$ enhanced iodination after $1 \mathrm{~h}$ and $18 \mathrm{~h}$ exposure, but decreased it, overcoming TSH stimulation, after $42 \mathrm{~h}$ (38). Likewise, in intact porcine thyroid follicles, IL-1 $\beta$ decreased iodide uptake with no effect on proliferation or cAMP formation (39). Conflicting results were reported as to the effects of interferon- $\gamma($ IFN- $\gamma)$. An increase in both basal and TSH-stimulated iodide uptake was reported in FRTL-5 cells $(36,40)$, whereas an inhibition of TSH-stimulated iodide uptake was observed in human thyrocytes after 5-7 days of culture $(39,40)$. This issue is further complicated by the observation that TNF- $\alpha$ potentiated the increase of TSH-stimulated iodide uptake caused by IFN- $\gamma$ in FRTL-5 cells (36) and the inhibition of TSHstimulated iodide uptake produced by the same cytokine in human thyrocytes $(41,42)$ (Table 1 ).

Inhibition of thyroglobulin $(\mathrm{Tg})$ synthesis by cytokines was reported. In cultured human thyrocytes IL- $1 \alpha$ and IL-1 $\beta$ decreased TSH-stimulated Tg mRNA levels, although no effect was apparent on basal Tg mRNA levels (43) (Table 1). At variance, other reports showed that the reduction in the synthesis of $\mathrm{Tg}$ caused by both IL-1 $\alpha$ (44) and TNF- $\alpha(45,46)$ in human thyrocytes was associated with a decrease in cAMP production. Other studies demonstrated that IL-6 had only marginal effects on $\mathrm{Tg}$ synthesis in cultured human thyrocytes, suggesting that IL- 1 effects are not mediated by IL- 6 induction (47). An inhibitory effect on TSH-stimulated $\mathrm{Tg}$ synthesis and secretion was also produced by IFN- $\gamma$ both in cultured human thyrocytes (48) and in FRTL-5 cells (49) (Table 1). Similar inhibition of TSH-stimulated $\mathrm{Tg}$ secretion was caused by IFN- $\gamma$ in thyrocytes from Graves' disease patients (50).

Several studies documented the effects of cytokines on thyroid hormone synthesis and secretion. IL- $1 \alpha$ and IL- $1 \beta$ caused a dose-dependent decrease in thyroid peroxidase (TPO) mRNA levels in cultured human thyrocytes from patients with Graves' disease (51) (Table 1). Similar results were obtained, using the same cell system, with IL-6 (52) and IFN- $\gamma$ (53). The latter cytokine also reduced the basal and TSHstimulated TPO content of cultured human thyrocytes (54). In a human thyrocyte system, IL- $1 \alpha$ and IL- $1 \beta$, as well as TNF- $\alpha$ and IFN- $\gamma$, decreased $\left[{ }^{125}\right.$ I] iodothyronine release in a dose-dependent manner (42). A decrease in TSH-stimulated $\mathrm{T}_{3}$ secretion was observed in cultured human thyrocytes incubated with IFN- $\gamma$ (41), IL-1 (42), or TNF- $\alpha$ (42) (Table 1). IL-6 also inhibited TSHstimulated $\mathrm{T}_{3}$ secretion in cultured human thyrocytes (52), but in other studies this effect of IL-6 could be obtained, using human thyroid follicles, only in the presence of soluble IL-6 receptor, which binds the cytokine and potentiates its action (55) (Table 1).

Conflicting results were reported on the growth effects of cytokines. An increase in tritiated thymidine incorporation into human thyrocytes and FRTL- 5 cells $(23,43)$ was caused by IL- 1 , but the opposite effect occurred in the presence of TSH (56) (Table 1). This inhibitory effect of IL-1 in the presence of TSH was also reported in papillary thyroid carcinoma cells (57). Inhibition of thyroid cell proliferation might be mediated by IL-1-stimulated prostaglandin $\mathrm{E}_{2}$ production (23). In different studies IFN- $\gamma$ caused either an increase (36, $49)$ or a decrease (58) in tritiated thymidine incorporation, IFN- $\gamma$ decreased $(41,59)$ and TNF- $\alpha$ stimulated (58) proliferation of human thyrocytes (Table 1). Cell 
Table 1 Effects of cytokines on thyroid function in vitro.

\begin{tabular}{|c|c|c|c|c|}
\hline Parameter & Cytokine & Cell system & Effect & Reference \\
\hline lodide uptake & $\begin{array}{l}\text { TNF- } \alpha^{*} \\
\text { IL-1 } \\
\text { IFN- } \gamma\end{array}$ & $\begin{array}{l}\text { FRTL-5 } \\
\text { Thyroid cancer } \\
\text { FRTL-5 } \\
\text { Porcine thyrocytes } \\
\text { Porcine thyroid follicle } \\
\text { FRTL-5 } \\
\text { Human thyrocytes }\end{array}$ & $\begin{array}{l}\text { Decreased }^{* *} \\
\text { Decreased }^{* *} \\
\text { Decreased }^{* *} \\
\text { Increased/decreased } \\
\text { Decreased } \\
\text { Increased } \\
\text { Decreased } \\
\end{array}$ & $\begin{array}{l}21,23 \\
21 \\
37 \\
38 \\
39 \\
36,40 \\
41,42\end{array}$ \\
\hline Thyroglobulin synthesis & $\begin{array}{l}\text { IL-1 } \alpha \\
\text { IL-1 } \beta \\
\text { IL-6 } \\
\text { IFN- } \gamma \\
\text { TNF- } \alpha\end{array}$ & $\begin{array}{l}\text { Human thyrocytes } \\
\text { Human thyrocytes } \\
\text { Human thyrocytes } \\
\text { Human thyrocytes } \\
\text { FRTL-5 } \\
\text { Graves' thyrocytes } \\
\text { Human thyrocytes }\end{array}$ & $\begin{array}{l}\text { Decreased mRNA } \\
\text { Decreased mRNA } \\
\text { No effect } \\
\text { Decreased mRNA } \\
\text { Decreased mRNA } \\
\text { Decreased } \\
\text { Decreased }\end{array}$ & $\begin{array}{l}43 \\
43 \\
47 \\
48 \\
49 \\
50 \\
45,46\end{array}$ \\
\hline lodination & $\begin{array}{l}\text { IL-1 } \alpha \\
\text { IL-1 } \beta \\
\text { IL-6 } \\
\text { IFN- } \gamma\end{array}$ & $\begin{array}{l}\text { Graves' thyrocytes } \\
\text { Graves' thyrocytes } \\
\text { Graves' thyrocytes } \\
\text { Graves' thyrocytes } \\
\text { Human thyrocytes }\end{array}$ & $\begin{array}{l}\text { Decreased TPO mRNA } \\
\text { Decreased TPO mRNA } \\
\text { Decreased TPO mRNA } \\
\text { Decreased TPO mRNA } \\
\text { Decreased TPO content }\end{array}$ & $\begin{array}{l}51 \\
51 \\
52 \\
53 \\
54\end{array}$ \\
\hline Thyroid hormone secretion & $\begin{array}{l}\text { IL-1 } \\
\text { IL-6**** } \\
\text { TNF- } \alpha \\
\text { IFN- } \gamma\end{array}$ & $\begin{array}{l}\text { Human thyrocytes } \\
\text { Human thyrocytes } \\
\text { Human thyroid follicle } \\
\text { Human thyrocytes } \\
\text { Human thyrocytes }\end{array}$ & $\begin{array}{l}\text { Decreased } T_{3} \text { secretion** } \\
\text { Decreased } T_{3} \text { secretion }^{* *} \\
\text { Decreased } T_{3} \text { secretion }^{\star * * * *} \\
\text { Decreased } T_{3} \text { secretion }^{\star *} \\
\text { Decreased } T_{3} \text { secretion }^{\star *}\end{array}$ & $\begin{array}{l}42 \\
52 \\
55 \\
42 \\
41\end{array}$ \\
\hline Growth effects & $\begin{array}{l}\text { IL-1 } \\
\text { IFN- } \gamma \\
\text { TNF- } \alpha\end{array}$ & $\begin{array}{l}\text { Human thyrocytes } \\
\text { FRTL-5 } \\
\text { FRTL-5 } \\
\text { Human thyrocytes } \\
\text { Human thyrocytes } \\
\text { Human thyrocytes }\end{array}$ & $\begin{array}{l}\text { Increased thymidine uptake } \\
\text { Increased thymidine uptake } \\
\text { Increased thymidine uptake } \\
\text { Decreased thymidine uptake } \\
\text { Decreased proliferation } \\
\text { Increased proliferation }\end{array}$ & $\begin{array}{l}43 \\
23 \\
36,49 \\
58 \\
41,59 \\
58\end{array}$ \\
\hline TSH synthesis and secretion & $\begin{array}{l}\text { IL-1 } \beta \\
\text { TNF- } \alpha\end{array}$ & $\begin{array}{l}\text { Rat pituitary cells } \\
\text { Dispersed pituitary cells } \\
\text { Rat pituitary cells }\end{array}$ & $\begin{array}{l}\text { Decreased TSH } \\
\text { Increased TSH } \\
\text { Decreased TSH }\end{array}$ & $\begin{array}{l}60 \\
62 \\
60\end{array}$ \\
\hline Thyroid hormone binding proteins & $\begin{array}{l}\text { IL-6 } \\
\text { TNF- } \alpha\end{array}$ & $\begin{array}{l}\text { Hep G2 } \\
\text { Human, mouse hepatocytes }\end{array}$ & $\begin{array}{l}\text { Decreased TBG, TTR, albumin } \\
\text { Decreased albumin }\end{array}$ & $\begin{array}{l}63 \\
66\end{array}$ \\
\hline
\end{tabular}

* TNF- $\alpha$ potentiated IFN- $\gamma$ increase of TSH-stimulated iodide uptake in FRTL- 5 cells and IFN- $\gamma$ decrease of TSH-stimulated iodide uptake in human thyrocytes.

** Effective only on TSH-stimulated iodide uptake.

$* * *$ Increased after $1 \mathrm{~h}$ or $18 \mathrm{~h}$ exposure, decreased after $42 \mathrm{~h}$ exposure.

$* * * *$ In human thyroid follicles this effect was obtained only in the presence of soluble IL-6 receptor (55).

$* * * *$ Only in the presence of soluble IL-6 receptor.

***** No effect of TRH-stimulated TSH release (60); possibly mediated by increased somatostatin release (61).

aging enhanced the sensitivity of the cells to the cytotoxic effects of TNF- $\alpha$ (58).

With regard to regulation of TSH synthesis and secretion, in rat anterior pituitary cells IL- $1 \beta$ and TNF- $\alpha$ caused a significant decline in TSH release without affecting the release of other pituitary hormones (60) (Table 1). Thyrotropin-releasing hormone (TRH)induced TSH release was not affected by $\mathrm{IL}-1 \beta$, suggesting that TRH might overcome the inhibitory effect of the cytokine (60); in addition, the pituitary uptake of radioiodinated thyroid hormones did not change in the presence of IL-1 $\beta$ (60), implying that the cytokine effect might not be mediated by an increased uptake (and inhibitory effect) of thyroid hormones. Other studies postulated that cytokines, in particular IL-1 $\beta$, might exert their effect on TSH release indirectly, through an enhancement of potassium-stimulated release of somatostatin from the hypothalamus (61). Reported results are not unequivocal, since IL- $1 \beta$ was also reported to stimulate TSH release from dispersed anterior pituitary cells (62).

Cytokines can also affect the synthesis and release of thyroid hormone-binding proteins. In human hepatoblastoma-derived (Hep G2) cells, IL-6 caused a reduction in the synthesis of $\mathrm{T}_{4}$-binding globulin (TBG), transthyretin (TTR) and albumin, acting at transcriptional levels (63) (Table 1). Interestingly, in the same cell system, IL-6 caused a decrease also in corticosteroidbinding globulin (CBG) synthesis, acting at a posttranscriptional level, probably through a decreased stability of CBG mRNA (64). Albumin gene expression was reduced also by TNF- $\alpha$ in humans and mice $(65$, 
66) (Table 1). It is worth noting that in Hep G2 cells IL-6 stimulated the synthesis of antitrypsin and antichymotrypsin, two major acute phase proteins showing a high degree of homology with TBG (63). There is no evidence that changes of thyroid function tests in NTI may be attributed to the effects of acute phase proteins.

In summary, although to some extent conflicting due to different cell systems and experimental conditions, in vitro studies provided a large body of evidence suggesting that cytokines may influence thyroid function either directly or indirectly. All steps of thyroid hormone synthesis, from iodide uptake to thyroid hormone secretion, may be affected by cytokines, the effects of which are generally inhibitory. Due to the complexity of the cytokine network, it is difficult, however, to relate results of in vitro studies, which utilize chemically defined experimental conditions, to the in vivo situation which results from the complicated interplay of different cytokines. Experiments with single cytokines or even with a combination of cytokines may to some extent be misleading because they necessarily do not consider the milieu of other cytokines and hormones that may profoundly affect the action of an individual cytokine on cells.

\section{Effects of cytokines in the animal in vivo}

An interesting animal model of experimental NTI is the injection of bacterial endotoxin (lipopolysaccharide, LPS) (67). Injection of a single, sublethal dose of LPS to mice resulted in systemic illness with hypothermia, induction of TNF- $\alpha$ and IL- 6 after $1-2 \mathrm{~h}$, decrease of hepatic $5^{\prime}$-DI after $4 \mathrm{~h}$, decrease of $\mathrm{TT}_{4}$ and $\mathrm{TT}_{3}$ after $8 \mathrm{~h}$, and of $\mathrm{FT}_{4}$ and $\mathrm{FT}_{3}$ after $24 \mathrm{~h}$, with no change in TSH concentration (68). This temporal relationship might imply a cause-effect relationship between the increase in serum cytokine levels and the decrease in serum thyroid hormone concentrations. However, direct administration of TNF- $\alpha$ and IL- 6 had no effect on thyroid function, whereas IFN- $\gamma$ caused a dosedependent decrease in serum $\mathrm{TT}_{4}, \mathrm{TT}_{3}$ and $\mathrm{FT}_{3}$ concentrations, and IL- $1 \alpha$ caused systemic illness and a transient decrease in $5^{\prime}$-DI mRNA (68). This study thus suggested that LPS-induced ESS in mice is best explained, at least in an acute setting, by a combination of a direct thyroidal effect of IFN- $\gamma$ and an extrathyroidal inhibition of $5^{\prime}$-DI by IL- $1 \alpha(68)$. While the reduction in serum $\mathrm{T}_{3}$ might be attributed to the diminished $5^{\prime}$-DI activity, the decrease in serum $\mathrm{T}_{4}$ implies a direct effect at the thyroid level by LPS.

To evaluate further the role of IL-6, LPS was administered to IL- 6 knock-out mice. While the decrease in serum $\mathrm{T}_{4}$ concentration was similar in IL-6 knock-out and wild type mice, the decrease in serum $\mathrm{T}_{3}$ concentration, as well as the reduction in 5'-DI activity, was smaller in IL-6 knock-out mice, suggesting a contribution of IL-6 to the pathogenesis of ESS (69). This would also be supported by the finding that immunoneutralization of
IL-6 did not prevent LPS-induced decreases in serum $\mathrm{TT}_{3}$ and $\mathrm{TT}_{4}$ concentrations, but it reduced the LPS-induced decrease in $5^{\prime}$-DI activity, while no effect was observed after immunoneutralization of IL- $1, \mathrm{TNF}-\alpha$ and IFN- $\gamma$ (70). The acute subcutaneous administration of IL-6 $(5 \mu \mathrm{g})$ to rats was associated with a decrease in serum $\mathrm{TT}_{4}, \mathrm{TT}_{3}$ and $\mathrm{TSH}$ concentrations $(71,72)$, while the $\mathrm{T}_{4} / \mathrm{T}_{3}$ ratio decreased, suggesting that $\mathrm{T}_{4}$ deiodination was not affected (72) (Table 2). IL-6 did not affect the pituitary TSH content, TSH- $\beta$ mRNA abundance, or hypothalamic TRH content (71). Changes in serum thyroid hormone concentrations could effectively be ascribed to IL- 6 , since they could be prevented by preincubation of IL-6 with its neutralizing antibody (72). The continuous intraperitoneal infusion of IL-6 ( $15 \mu \mathrm{g} /$ day for 7 consecutive days) in rats was associated with a transient decrease in serum $\mathrm{TT}_{4}$ and $\mathrm{TSH}$, although less than that caused by IL-1 (73) (Table 2). In the latter study, hypothalamic pro-TRH mRNA and pituitary TSH- $\beta$ mRNA were unaffected by IL- 6 , suggesting that the effects of IL-6 on TSH might not necessarily be associated with a decreased synthesis of thyrotropin (73). On the other hand, the observation that the intracerebroventricular administration of IL- 6 to rats was followed by a decrease in serum TSH and an increase in serum adrenocorticotropin (ACTH) concentrations, while these changes could be reproduced in hemipituitaries only for ACTH, but not for TSH, suggested that the action of IL- 6 on TSH might be exerted predominantly at the hypothalamic levels (74).

In rats, a single injection of $\mathrm{IL}-1 \beta$ decreased serum $\mathrm{TT}_{3}, \mathrm{TT}_{4}$ and $\mathrm{TSH}$ concentrations without affecting 5'-DI (75), whereas persistent changes in serum $\mathrm{TT}_{4}$ and $\mathrm{TT}_{3}$ levels were found during continuous infusion of the cytokine at doses not causing systemic disease (76) (Table 2). These changes, mostly related to decreased thyroid hormone binding to $\mathrm{T}_{4}$-binding prealbumin, were accompanied by a decrease in both basal and TRHstimulated $\mathrm{TSH}$ levels, while $\mathrm{rT}_{3}$ remained unchanged and $5^{\prime}$-DI was apparently unaffected (76). The effect of IL-1 on $5^{\prime}$-DI activity is not unequivocal, since an increase in liver $5^{\prime}$-DI activity was also reported in IL-1treated mice (77). Likewise, a stimulation of $5^{\prime}$-DI activity was reported in the brain cortex of IL-1-treated rats (75). The continuous intraperitoneal infusion of IL-1 $(4 \mu \mathrm{g} /$ day $)$ in rats for 1,2 or 7 days caused a decrease in serum $\mathrm{TT}_{4}, \mathrm{TT}_{3}, \mathrm{FT}_{4}$ and $\mathrm{TSH}$ concentrations (73) (Table 2); changes in TSH were associated with a decrease in pro-TRH and TSH- $\beta$ mRNAs, indicating a site of action of the cytokine at both the hypothalamic and pituitary level (73). Interestingly, another study showed a prolonged effect of IL-1 $\alpha$ on mouse thyroid function; after a rapid decrease in serum $\mathrm{TT}_{4}$ concentration following administration of 1 or $15 \mu \mathrm{g}$ IL- $1 \alpha$ daily for 7 consecutive days, serum $\mathrm{TT}_{4}$ levels normalized after cytokine discontinuation, but decreased again 3 weeks after its withdrawal, in association with a decreased thyroid responsiveness to 
Table 2 Effects of cytokines on thyroid function in animals.

\begin{tabular}{|c|c|c|c|}
\hline Cytokine & Animal species & Effects & Reference \\
\hline IL-1 $\beta$ & $\begin{array}{l}\text { Rat }^{*} \\
\text { Rat }^{\star *}\end{array}$ & $\begin{array}{l}\text { Decreased } \mathrm{TT}_{4}, \mathrm{TT}_{3}, \mathrm{TSH} \\
\text { Unchanged } \mathrm{rT}_{3}, 5^{\prime} \text {-DI } \\
\text { Decreased } \mathrm{TT}_{4}, \mathrm{TT}_{3}, \mathrm{FT}_{4}, \mathrm{TSH}\end{array}$ & $\begin{array}{l}75 \\
75 \\
73,76\end{array}$ \\
\hline TNF- $\alpha$ & $\begin{array}{l}\operatorname{Rat}^{* * * *} \\
\text { Rat }^{* \star * * * *}\end{array}$ & $\begin{array}{l}\text { Decreased } \mathrm{TT}_{3}, \mathrm{TT}_{4} \\
\text { Increased } \mathrm{T}_{3} / \mathrm{T}_{4} \\
\text { Unchanged } \mathrm{rT}_{3} \\
\text { Decreased } \mathrm{T}_{3}-\mathrm{T}_{4} \text { response to } \mathrm{TSH} \\
\text { Decreased } \mathrm{TT}_{4}, \mathrm{TT}_{3}, \mathrm{FT}_{4}, \mathrm{TSH} \\
\text { Decreased hypothalamic TRH } \\
\text { Decreased } \mathrm{TSH}_{\text {glycosylation }} \\
\text { Decreased } 5^{\prime}-\mathrm{DI} \mathrm{I}^{\star \star \star \star *} \\
\text { Decreased } \mathrm{TT}_{4}, \mathrm{TT}_{3} \\
\text { Unchanged basal and TRH-stimulated TSH } \\
\text { Unchanged } 5^{\prime} \text {-DI }\end{array}$ & $\begin{array}{l}79 \\
79 \\
79 \\
79 \\
21 \\
21 \\
21 \\
80 \\
77 \\
80 \\
77\end{array}$ \\
\hline IL-6 & $\begin{array}{l}\text { Rat }^{*} \\
\text { Rat }^{* *}\end{array}$ & $\begin{array}{l}\text { Decreased } \mathrm{TT}_{4}, \mathrm{TT}_{3}, \mathrm{TSH} \\
\text { Decreased } \mathrm{TT}_{4}, \mathrm{TSH}\end{array}$ & $\begin{array}{l}71,72 \\
73\end{array}$ \\
\hline $\mathrm{IL}-2$ & Dog & Decreased $\mathrm{TT}_{4}, \mathrm{TT}_{3}$ & 81 \\
\hline
\end{tabular}

${ }^{*}$ Acute experiment.

${ }^{* *}$ Continuous intraperitoneal infusion.

$* * * 3$ days.

$* * * * 1$ day.

$* * * * *$ Increased after 3 days.

$* * * * * *$ Continuous infusion.

TSH stimulation probably related to a decline in TSHstimulated cAMP production (78).

The acute administration of TNF- $\alpha(1-100 \mu \mathrm{g} /$ day for 3 days) to mice was followed by a reduction in serum $\mathrm{TT}_{3}$ and $\mathrm{TT}_{4}$ concentrations, an increase in $\mathrm{T}_{3} / \mathrm{T}_{4}$ ratio, and a decreased $\mathrm{T}_{3}$ and $\mathrm{T}_{4}$ response to TSH, while $5^{\prime}$-DI activity was unchanged (79) (Table 2). One-day treatment of rats with TNF- $\alpha$ caused a decrease in serum $\mathrm{TT}_{4}, \mathrm{FT}_{4}, \mathrm{TT}_{3}$ and $\mathrm{TSH}$ concentrations, a reduction in hypothalamic TRH, an impaired glycosylation of TSH, a reduction in TSH- $\beta$ mRNA, and a reduction in $\mathrm{T}_{3}$ and $\mathrm{T}_{4}$ release (21) (Table 2). 5'-DI activity was reduced after 1 day of TNF- $\alpha$ treatment, but it increased after 3 days of treatment (21). Finally, the continuous infusion of TNF- $\alpha$ in rats in subpyrogenic and subanorectic doses caused a reduction in serum $\mathrm{TT}_{4}$ and $\mathrm{TT}_{3}$ concentrations without changes in basal and TRH-stimulated TSH concentrations, and apparently no changes in $5^{\prime}$-DI activity (80) (Table 2).

The continuous infusion of IL- 2 in dogs ( 4 days per week for 2 weeks) caused a significant reduction in serum concentrations of $\mathrm{TT}_{4}(25-50 \%$ of pretreatment values) and $\mathrm{TT}_{3}$ (20-30\% of pretreatment values), although cytokine administration was associated with severe systemic disease with diarrhea, vomiting and lethargy (81). Whether changes in thyroid hormone concentrations were a direct effect of IL-2 or were mediated by the induction of other cytokines by IL-2 was not established (81).

In summary, administration of cytokines to animals did not produce unequivocal results. Basically, a decrease in serum thyroid hormone concentrations was often observed, sometimes in association with an inhibition of TSH secretion. Both central (hypothalamus-pituitary) and peripheral (thyroid, liver $5^{\prime}$-DI) actions of cytokines are likely. Differences were often reported between the acute and chronic effects of the same cytokine. It cannot be ruled out that, in addition to differences in animal species and experimental design, nutritional deficiencies may have contributed to the above changes and differences in the results of different studies. In this regard, it should be pointed out that control groups of pair-fed animals are lacking in many of the above studies. An inhibition of $5^{\prime}$-DI has not consistently been reported in animals. This might indicate that either the experimental design did not fully reproduce the situation in humans, or factors other than cytokines are indeed responsible for changes in thyroid function seen in ESS.

\section{Serum cytokine and cytokine receptor protein concentrations in patients with NTI}

Serum $\mathrm{T}_{3}$ concentration was lower in 29 nursing home residents who had detectable serum TNF- $\alpha$ concentration than in the 36 with undetectable TNF- $\alpha$, while there was no differences in serum $\mathrm{T}_{3}$ levels between patients with detectable or undetectable IL- $1 \alpha$ concentrations (82) (Table 3). No subject had an increase in serum $\mathrm{rT}_{3}$ concentrations (82). Increased serum TNF- $\alpha$ and IL- 6 (but not IL-1 $\beta$ ) concentrations were reported in 65 patients with African trypanosomiasis (sleeping sickness) (83); a negative correlation between TNF- $\alpha$ 
Table 3 Serum cytokine and cytokine receptor protein (Rp) levels in NTI.

\begin{tabular}{lll}
\hline Cytokine & Serum levels & Reference \\
\hline TNF- $\alpha$ & Often increased & 82,83 \\
IL-6 & Usually normal & 84 \\
IL-8 & Increased & $83,85-93$ \\
IL-10 & Undetectable & 94 \\
IFN- $\gamma$ & Undetectable & 94 \\
sTNF- $\alpha$ Rp55 & Undetectable & 94 \\
sTNF- $\alpha$ Rp 75 & Increased & 95 \\
sIL-2 receptor & Increased & 95 \\
IL-1 receptor antagonist & Increased & 95 \\
\end{tabular}

Included in the different series were: nursing home residents (82), patients with African trypanosomiasis (83), children with acute respiratory infections (88), brain-dead patients (89), patients with recurrent breast cancer (90), patients submitted to surgery (91) or cardiopulmonary bypass (92), patients with chronic liver, renal, cardiac and gastrointestinal disorders or diabetes mellitus $(84,85-$ $87,93,94)$.

and $\mathrm{FT}_{3}$ values was also found (83). It should be noted that patients in this study had an increase in the mean serum TSH concentration compared with control subjects, suggesting that changes in thyroid hormone levels can be more likely ascribed to primary thyroid failure (83). Serum $\mathrm{rT}_{3}$ concentration were normal in sleeping sickness (83). The relevance of TNF- $\alpha$ changes in NTI patients was questioned, based on the observation that serum concentration of the cytokine was elevated in only 1 of 13 NTI patients (84); no relationship was found between TNF- $\alpha$ and thyroid hormone concentrations, with the exception of a slight correlation with $\mathrm{FT}_{4}$ values, possibly related to a TNF- $\alpha$-induced increase in FFA levels (84) (Table 3).

An increase in serum IL-6 concentrations was reported in NTI patients, especially those with low $\mathrm{T}_{3}$ concentration $(83,85-87)$ (Table 3). Serum IL-6 levels were negatively correlated with serum $\mathrm{FT}_{3}$ and positively correlated with serum $\mathrm{rT}_{3}$ concentrations (86). Increased serum IL-6 concentrations were also found in the majority of 59 children with acute respiratory infections (88), in brain-dead patients (89) and in women with breast cancer (90), with an inverse relationship with serum $\mathrm{T}_{3}$ values and the $\mathrm{T}_{3} / \mathrm{T}_{4}$ ratio (88-90). Interestingly, TNF- $\alpha$ and IL- 1 concentrations were generally normal $(88,89)$. A temporal relationship between IL- 6 and thyroid hormone variations was observed in the post-surgery period, since the increase in serum IL-6 concentration occurred early and preceded the decrease in serum $\mathrm{T}_{3}$ concentration both in adults (91) and in children undergoing cardiopulmonary bypass (92). A recent evaluation of 270 inpatients with NTI, while confirming changes in IL-6 levels and their relationship with variations in serum thyroid hormone concentrations, showed that the IL- 6 increase was modest in patients with acute or chronic renal disorders, in spite of the concomitant decrease in serum thyroid hormone concentrations, suggesting that, at least in this form of NTI, IL-6 is not the only or most important causative factor responsible for alterations in thyroid hormone metabolism (93).

Other cytokines, including IL-8, IL-10 and IFN- $\gamma$, were undetectable and not related to changes in serum thyroid hormone concentration of NTI patients (94) (Table 3).

An increase in serum soluble cytokine receptor proteins ( $\mathrm{Rp}$ ) was reported in NTI patients, in particular soluble TNF- $\alpha$ receptor protein 55 (sTNF- $\alpha$ Rp55), soluble TNF- $\alpha$ receptor protein 75 (sTNF- $\alpha$ Rp75) and soluble IL-2 receptor (95) (Table 3 ). Although all these receptor proteins, as well as IL-1 receptor antagonist, showed a negative correlation with serum $\mathrm{T}_{3}$ values, stepwise multiple regression indicated that only sTNF- $\alpha$ Rp75 and IL-6 were independent determinants of $\mathrm{T}_{3}$, accounting for 35 and $14 \%$, respectively, of $\mathrm{T}_{3}$ changes in NTI (95). Since IL-6 and TNF- $\alpha$ Rp are considered as anti-inflammatory proteins, this relationship might be regarded as a mechanism by which the body counteracts systemic disease.

In summary, increased concentrations of IL-6 and, to a lesser extent, TNF- $\alpha$ are often found in NTI patients. The increase in IL- 6 levels might reflect stimulation of its synthesis by other cytokines such as IL- 1 and TNF- $\alpha$ that might be undetectable in the circulation because they are only transiently increased and act mainly via autocrine and paracrine mechanisms. Thus, in view of the mentioned interaction of cytokines with each other and with hormones, determination of serum cytokine concentration may unravel only part of the story. The increased levels of cytokine receptor proteins probably reflect the activation of the cytokine network during the acute phase reaction occurring during acute and chronic disorders (7). All the above described studies do not answer the question of whether the increase in cytokine circulating levels is the cause of changes in thyroid hormone concentration and metabolism or reflects a concomitant (and independent) alteration due to systemic disease.

\section{Effects of cytokine administration in humans}

Only a few studies so far have evaluated the relationship of administration of cytokines to humans with changes in thyroid economy. It should be pointed out that all these studies carry the limitation of being open, unrandomized and uncontrolled.

Infusion of TNF- $\alpha\left(50 \mu \mathrm{g} / \mathrm{m}^{2}\right)$ for $5.5 \mathrm{~h}$ in six healthy volunteers was followed, throughout the $10.5 \mathrm{~h}$ of follow-up, by a significant decrease in serum $\mathrm{TT}_{3}$ and $\mathrm{TSH}$ concentrations and a significant increase in $\mathrm{rT}_{3}$ values, while $\mathrm{FT}_{4}$ showed a transient increase, synchronous with and possibly related to the increase in FFA levels (96) (Table 4). 
Table 4 Effects of cytokine administration in humans.

\begin{tabular}{|c|c|c|c|c|}
\hline Cytokine & Dose & Subjects & Effects & Reference \\
\hline TNF- $\alpha$ & $50 \mu \mathrm{g} / \mathrm{m}^{2}$ & Six healthy volunteers & $\begin{array}{l}\text { Decreased } \mathrm{TT}_{3}, \mathrm{TSH} \\
\text { Increased } \mathrm{rT}_{3}, \mathrm{FFA}\end{array}$ & 96 \\
\hline IFN- $\alpha 2 b$ & $5 \times 10^{6} \mathrm{U} / \mathrm{m}^{2}$ & Eight healthy volunteers & $\begin{array}{l}\text { Decreased } \mathrm{TT}_{3}, \mathrm{TSH} \\
\text { Increased } \mathrm{rT}_{3}, \mathrm{IL}-6 \\
\text { Unchanged } \mathrm{TT}_{4}\end{array}$ & 100 \\
\hline \multirow[t]{2}{*}{ IL-6 } & $150 \mu \mathrm{g}$ i.v. (4 h) & Eight renal cancer patients & $\begin{array}{l}\text { Decreased } \mathrm{TT}_{3}, \mathrm{TSH} \\
\text { Increased } \mathrm{rT}_{3} \\
\text { Unchanged } \mathrm{TT}_{4}, \mathrm{FT}_{4}\end{array}$ & 101 \\
\hline & $150 \mu$ g s.c. (42 days) & Eight renal cancer patients & $\begin{array}{l}\text { Early changes, } \\
\text { subsequent normalization }\end{array}$ & 101 \\
\hline IL-2* & $3 \times 10^{6} \mathrm{U} / \mathrm{m}^{2}$ & Four hepatocarcinoma patients & Decreased $\mathrm{TT}_{4}, \mathrm{FT}_{4}, \mathrm{TT}_{3}$ & 108 \\
\hline
\end{tabular}

* Associated with lymphokine-activated killer cells.

IFN- $\alpha$ long-term administration for chronic hepatitis and malignant disorders can be responsible for thyroid dysfunction, both hyper- (97) and hypothyroidism (98), usually accompanied by a rise in circulating thyroid autoantibodies. Withdrawal of the drug was usually associated with normalization of thyroid function (99) (Table 4). Subcutaneous injection of IFN- $\alpha 2 b$ $\left(5 \times 10^{6} \mathrm{U} / \mathrm{m}^{2}\right)$ in eight healthy volunteers significantly reduced, within a few hours, serum TSH and $\mathrm{TT}_{3}$, increased $\mathrm{rT}_{3}$ and did not affect $\mathrm{T}_{4}$ concentrations (100) (Table 4). The effect of IFN- $\alpha$ was slightly slower than that reported for $\mathrm{TNF}-\alpha$, possibly due to the different route of cytokine administration (intravenous for TNF- $\alpha$, subcutaneous for IFN- $\alpha$ ). Further to IFN- $\alpha$ administration, IL- 6 increased, while IL- 1 and TNF- $\alpha$ levels did not change, suggesting that the effects of IFN- $\alpha$ might be mediated, at least partially, by IL-6 (100).

The effects of IL- 6 were evaluated after either acute or chronic administration in patients with renal cancer (101). The acute $(4 \mathrm{~h})$ intravenous administration of $150 \mu \mathrm{g}$ IL-6 to eight patients was followed by a significant decrease in serum $\mathrm{TT}_{3}$ and TSH concentrations, with an increase in serum $\mathrm{rT}_{3}$ levels and no change in serum $\mathrm{TT}_{4}$ and $\mathrm{FT}_{4}$ concentrations (101) (Table 4$)$. On the other hand, the chronic (42 days) subcutaneous administration of $150 \mu \mathrm{g}$ daily of IL-6 to eight patients was associated with early and transient changes in thyroid parameters similar to the acute experiment, followed by normalization of thyroid hormone and TSH levels after a few weeks and even before discontinuation of the drug (101) (Table 4). This might suggest that, while IL-6 might contribute to the development of ESS, factors other than IL-6 could be involved in the persistence of changes in thyroid parameters during chronic illness.

Due to the effects that LPS has in the animal, experiments on the acute effects of this substance were carried out also in humans. The intravenous administration of LPS $(20 \mathrm{U} / \mathrm{kg})$ to 18 healthy volunteers was followed by a rapid decrease in serum $\mathrm{TT}_{4}, \mathrm{FT}_{4}$,
$\mathrm{TT}_{3}$ and TSH and a rise in $\mathrm{rT}_{3}$ concentrations (102). Interestingly, these changes could not be prevented by coinfusion of IL-1 receptor antagonist, apparently administered at a high molar excess, suggesting that IL-1 does not play a pivotal role in the pathogenesis of changes in thyroid economy encountered in mild endotoxemia (102). On the other hand, TNF- $\alpha$ and IL-6 are readily detected in the bloodstream after administration of low-dose endotoxin to humans (103, 104) and might be responsible for ESS changes.

Although treatment with IL-2 may cause hyper- or, more frequently, hypothyroidism (105-107), changes typical of ESS, such as a reduction in serum $\mathrm{TT}_{3}, \mathrm{TT}_{4}$ and $\mathrm{FT}_{4}$, with no changes in serum TSH concentrations, were also reported in four of eight patients with hepatocellular carcinoma after 16 courses of treatment with IL-2 (and lymphokine-activated killer cells) (108) (Table 4). The relative contribution of lymphokineactivated killer cells or disease itself is difficult to establish, but no abnormalities of thyroid function were seen in nine cancer patients receiving no active treatment (108).

In summary, the limited studies available demonstrated that TNF- $\alpha$, IFN- $\alpha$, IL- 6 and endotoxin administration is followed by rapid changes in thyroid parameters similar to those found in ESS. It should, however, be pointed out that most investigations were carried out acutely. The effects of acute cytokine administration might be related to the systemic (flulike) illness caused by the cytokine rather than to the effect of the cytokine itself. On the other hand, the rapidity with which changes in thyroid hormone and TSH concentrations occur after cytokine administration might imply that these changes do not merely constitute an adaptation to the long-standing catabolic state or caloric deprivation of NTI. Data on chronic administration of cytokines are scanty. Chronic administration of IL6 did not provide clear results (101), whereas chronic administration of IL-2 was associated with changes typical of ESS (108). Admittedly, controlled studies are warranted, because the latter results might simply reflect 
progression of neoplastic disease. Experiments in which the effects of cytokines are blocked by cytokine antagonists are also needed, because this approach might help to identify the specific role of individual cytokines. In humans, the only available study showed that IL-1 receptor antagonist did not block endotoxin-induced changes in thyroid parameters (102), while in the rat IL6 -induced thyroid hormone changes could be prevented by IL-6 immunoneutralization (72).

\section{Are cytokines responsible for ESS?}

The experimental and clinical data presented above underscore the concept that there are elements both in favor of and against a relevant role of cytokines in the pathogenesis of ESS.

\section{Elements against}

(1) Studies in vivo either in animals or in humans caused changes in thyroid function similar to those of ESS, but they often employed pharmacological doses of cytokines that might cause systemic disease responsible for thyroid function variations.

(2) Most studies in humans were carried out acutely, while controlled studies on chronic effects of cytokine administration are lacking.

(3) Serum concentrations of several cytokines are often normal in NTI.

(4) Serum concentrations of cytokines do not necessarily reflect paracrine or autocrine effects.

(5) 5'-DI activity is not always decreased by cytokines, both in in vivo and in vitro studies.

\section{Elements in favor}

(1) Increased concentrations of cytokines, especially IL-6, are often found in NTI patients and correlate with changes in thyroid hormone concentrations.

(2) Cytokines profoundly affect in vitro thyroid function, either directly or indirectly via regulation of TSH synthesis and secretion.

(3) The administration of cytokines in vivo mimic, at least acutely, changes of thyroid function tests occurring in NTI, and the induced changes in thyroid function tests occur so quickly that it is difficult to attribute them to cytokine-induced systemic disease.

(4) Neutralization of IL-6 effects by anti-IL-6 antibody was reported in animals.

Thus, while it seems certain that NTI is associated with an increased production and release of cytokines, the degree of cytokines involvement and their specific role in the pathogenesis of ESS remain to be clarified. One possibility is that NTI per se causes an increase in cytokine production and the latter is the only factor responsible for changes in ESS (Fig. 2). A second possibility is that illness, through mechanisms

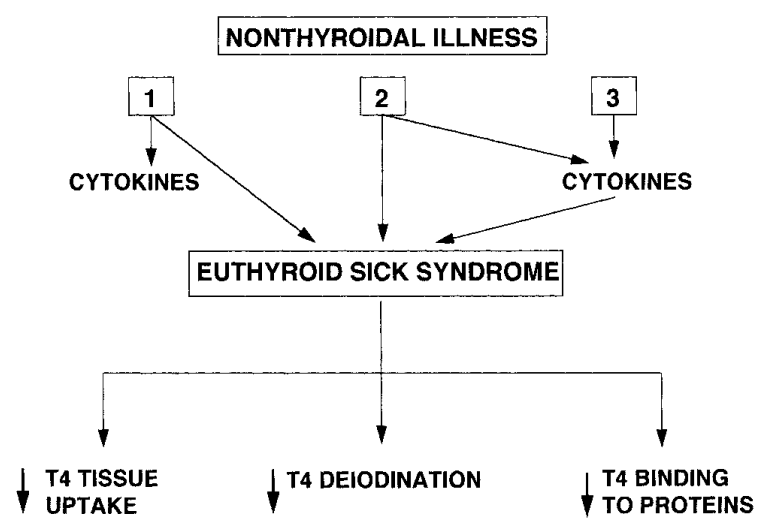

Figure 2 Possible relationship between cytokines and ESS. In model 1, nonthyroidal illness is, at the same time, responsible for ESS and the increased production of cytokines, but these are not involved in the pathogenesis of ESS. In model 3, nonthyroidal illness causes an increased production of cytokines, which are solely responsible for ESS. In model 2, cytokines contribute to the pathogenesis of ESS, but other mechanisms, cytokine-unrelated and disease-related, are also involved. Adapted and expanded from Wiersinga \& Boelen (7).

incompletely understood, produces both an increase in cytokine levels and changes in thyroid function tests, the latter being totally independent of cytokine variations (Fig. 2). The third and more likely model relates changes in thyroid parameters to both a direct effect of disease and the illness-related increase in cytokine production and release (Fig. 2). This model best fits with available data indicating that, in addition to the above discussed in vitro and in vivo effects of cytokines, other substances, such CMPF, indoxyl-sulfate, bilirubin and FFA, which reduce thyroid hormone transport into cells and thereby decrease peripheral $\mathrm{T}_{3}$ production, probably participate in the pathogenesis of ESS (7).

\section{Anticytokine strategy for ESS?}

If cytokines are involved in the pathogenesis of ESS, then control of their enhanced production and action might deserve consideration. Regulation of cytokine activity might be achieved through different mechanisms. Soluble cytokine receptors are highly selective inhibitors that bind cytokines and prevent their subsequent binding to their receptor: receptor antagonists and mutated cytokines bind to cytokine receptors, thus preventing subsequent receptor-induced signal transduction; antibodies to cytokines neutralize and thus antagonize cytokines; nonpeptidic antagonists (e.g. isothiazolone A) probably interfere with cytokine synthesis, receptor binding or signal transduction (109). Information on the effectiveness of anticytokine therapy is currently rather limited, and support from properly carried out controlled studies is warranted. With this limitation in mind, can an anticytokine strategy be envisaged for correction of ESS? First, although, as discussed above, growing evidence supports 
a role for cytokines in ESS, this remains to be definitely proven and defined. Secondly, it is unclear which cytokine should be blocked. Cytokines are related to each other in a very complex network, and regulate positively or negatively the expression of other cytokines; it is, therefore, difficult to imagine how to interrupt this interplay and cascade of events. In addition, it would be difficult to determine doses of the antagonist to be used and the length of treatment. Cost/benefit considerations should also be made, especially because, and this is the most important point, it remains to be ascertained whether changes in thyroid economy occurring in NTI really need to be corrected. A leading textbook states that '... change in thyroid function may serve the purpose of conserving energy by a diminished provision of biologically active thyroid hormone in order to compensate for the increased metabolic demands imposed by the disease ...' (110). In agreement with this concept, the use of thyroid hormones did not beneficially affect the course of NTI (111). The use of anticytokine strategies, although aimed at the purported mechanisms of ESS and not at their consequences in terms of thyroid economy, would probably not achieve better results.

\section{Acknowledgements}

We wish to thank Professor Aldo Pinchera for his continuous encouragement and advice. This work was supported in part by grants from the National Research Council (CNR, Rome, Italy) and by University of Pisa (Fondi di Ateneo).

\section{References}

1 Docter R, Krenning EP, de Jong M \& Hennemann G. The sick euthyroid syndrome: changes in thyroid hormone serum parameters and hormone metabolism. Clinical Endocrinology $199339499-518$.

2 Chopra IJ, Taing P \& Mikus L. Direct determination of free triiodothyronine $\left(\mathrm{T}_{3}\right)$ in undiluted serum by equilibrium dialysis/ radioimmunoassay. Thyroid $19966255-259$.

3 Engler D \& Burger AG. The deiodination of the iodothyronines and their derivatives in man. Endocrine Reviews $19845151-$ 184.

4 Kaptein EM, Feinstein EI, Nicoloff JT \& Massry SG. Serum reverse triiodothyronine and thyroxine kinetics in patients with chronic renal failure. Journal of Clinical Endocrinology and Metabolism 198357 181-189.

5 LoPresti JS, Fried JC, Spencer CA \& Nicoloff JT. Unique alterations of thyroid hormone indices in the acquired immunodeficiency syndrome (AIDS). Annals of Internal Medicine $1989110970-$ 975.

6 Woolf PD, Lee LA, Hamill RW \& McDonald JF. Thyroid test abnormalities in traumatic brain injury: correlation with neurologic impairment and sympathetic nervous system activation. American Journal of Medicine 198884 201-208.

7 Wiersinga WM \& Boelen A. Thyroid hormone metabolism in nonthyroidal illness. Current Opinion in Endocrinology and Diabetes $19963422-427$

8 Bartalena L, Pacchiarotti A, Palla R, Antonangeli L, Mammoli C, Monzani F et al. Lack of nocturnal serum thyrotropin (TSH) surge in patients with chronic renal failure undergoing regular maintenance hemofiltration: a case of central hypothyroidism. Clinical Nephrology 199034 30-34.

9 Arem R \& Deppe S. Fatal nonthyroidal illness may impair nocturnal thyrotropin levels. American Journal of Medicine 1990 $88258-262$.

10 Romijn JA \& Wiersinga WM. Decreased nocturnal surge of thyrotropin in nonthyroidal illness. Journal of Clinical Endocrinology and Metabolism 199070 35-42.

11 Bartalena L, Martino E, Brandi LS, Falcone M, Pacchiarotti A, Ricci $\mathrm{C}$ et al. Lack of nocturnal serum thyrotropin surge after surgery. Journal of Clinical Endocrinology and Metabolism 199070 293-296.

12 Bartalena L, Placidi GF, Martino E, Falcone M, Pellegrini L, Dell'Osso L et al. Nocturnal serum thyrotropin (TSH) surge and the TSH response to TSH-releasing hormone: dissociation in untreated depressives. Journal of Clinical Endocrinology and Metabolism 199071 650-655.

13 Lee H-Y, Suhl J, Pekary AE \& Hershman JM. Secretion of thyrotropin with reduced concanavalin-A binding activity in patients with severe nonthyroid illness. Journal of Clinical Endocrinology and Metabolism 198765 942-945.

14 Faber J, Kirkegaard C, Rasmussen B, Westh B, Busch-Sorensen M \& Jensen IW. Pituitary-thyroid axis in critical illness. Journal of Clinical Endocrinology and Metabolism 198765 315-320.

15 Chopra IJ. Euthyroid sick syndrome: is it a misnomer? Journal of Clinical Endocrinology and Metabolism 199782 329-334.

16 Lim CF, Bernard BF, de Jong M, Docter R, Krenning EP \& Hennemann G. A furan fatty acid and indoxyl sulfate are the putative inhibitors of thyroxine hepatocyte transport in uremia. Journal of Clinical Endocrinology and Metabolism 199376 318324.

17 Lim CF, Docter R, Visser TJ, Krenning EP, Bernard P, van Toor H et al. Inhibition of thyroxine transport into cultured rat hepatocytes by serum of nonuremic critically ill patients: effects of bilirubin and nonesterified fatty acids. Journal of Clinical Endocrinology and Metabolism 199376 1165-1172.

18 Everts ME, Lim CF, Moerings EPCM, Docter R, Visser TJ, de Jong $\mathrm{M}$ et al. Effects of a furan fatty acid and indoxyl sulfate on thyroid hormone uptake in cultured anterior pituitary cells. American Journal of Physiology 1995268 E974-E979.

19 Whitcher JT \& Evans SW. Cytokines in disease. Clinical Chemistry $1990361269-1281$.

20 Svenson M, Kayser L, Hansen MB, Krogh Rasmussen A \& Bendtzen K. Interleukin-1 receptors on human thyroid cells and on the rat thyroid cell line FRTL-5. Cytokine 19913 125-130.

21 Pang H-P, Hershman JM, Chung M \& Pekary AE. Characterization of tumor necrosis factor- $\alpha$ receptors in human and rat thyroid cells and regulation of the receptors by thyrotropin. Endocrinology 1989125 1783-1788.

22 Grubeck-Loebenstein B, Bichan G, Chantry D, Kassal H, Londei M, Pirich K et al. Analysis of intrathyroidal cytokine production in thyroid autoimmune disease: thyroid follicular cells produce interleukin- $1 \alpha$ and interleukin-6. Clinical and Experimental Immunology 198977 324-330.

23 Kawabe Y, Eguchi K, Shimomura C, Mine M, Otsubo T, Ueki Y et al. Interleukin-1 production and action in thyroid tissue. Journal of Clinical Endocrinology and Metabolism 198968 11741183.

24 Weetman AP, Bright-Thomas R \& Freeman M. Regulation of interleukin- 6 release by human thyrocytes. Journal of Endocrinology 1990127 357-361.

25 Del Prete GF, Mavilia C, Giudizi MG, De Carli M, Mastromauro C, Toccafondi R et al. IFN- $\gamma$ and TNF- $\alpha$ upregulate IL- 6 production by human thyrocytes. In: Cytokines: Basic Principles and Clinical Applications, pp 71-76. Eds S Romagnani \& AK Abbas. New York: Raven Press, 1990.

26 Iwamoto M, Sakihama T, Kimura N, Tasaka K \& Onaya T. Augmented interleukin 6 production by rat thyrocytes (FRTL-5): effect of interleukin $1 \beta$ and thyroid-stimulating hormone. Cytokine 19913 345-349. 
27 Diamant M, Kayser L, Rasmussen AK, Bech K \& Feldt-Rasmussen U. Interleukin-6 production by thyroid epithelial cells. Enhancement of interleukin-1. Autoimmunity $19911121-26$.

28 Kennedy RL, Jones TH, Davies R, Justice SK \& Lemoine NR. Release of interleukin- 6 by thyroid epithelial cells immortalized by simian virus 40 DNA transfection. Journal of Endocrinology $1992133477-482$.

29 Weetman AP, Bennett GL \& Wong WLT. Thyroid follicular cells produce interleukin-8. Journal of Clinical Endocrinology and Metabolism 199275 328-330.

30 Zheng RQH, Abeny E, Chu CQ, Field M, Grubeck-Loebenstein B, Maini RN et al. Detection of interleukin-6 and interleukin-1 production in human thyroid epithelial cells by non-radioactive in situ hybridization and immunohistochemical methods. Clinical and Experimental Immunology 199183 314-319.

31 Rutenfrantz I, Kruse A, Rink L, Wenzel B, Arbholdt H \& Kirchner $H$. In situ hybridization of the mRNA for interferon- $\gamma$, interferon$\alpha$, interferon- $\beta$, interleukin- $\beta$ and interleukin- 6 and characterization of infiltrating cells in thyroid tissues. Journal of Immunological Methods 1992148 233-242.

32 Ajjan RA, Watson PF \& Weetman AP. Detection of IL-12, IL-13, and IL-15 messenger ribonucleic acid in the thyroid of patients with autoimmune thyroid disease. Journal of Clinical Endocrinology and Metabolism 199782 666-669.

33 Weetman AP. Recent progress in thyroid autoimmunity: an overview for the clinician. Thyroid Today 199629 1-9.

34 Bartalena L, Brogioni S, Grasso L, Rago T, Vitti P, Pinchera A \& Martino E. Interleukin-6: a marker of thyroid-destructive processes? Journal of Clinical Endocrinology and Metabolism 1994 79 1424-1427.

35 Heufelder AE. Pathogenesis of Graves' ophthalmopathy: recent controversies and progress. European Journal of Endocrinology $1995135532-541$.

36 Zakarija M \& McKenzie JM. Influence of cytokines on growth and differentiated function of FRTL-5 cells. Endocrinology 1989125 $1260-1265$

37 Pang H-P, Hershman JM, Smith V, Pekary AE \& Sugawara M. The mechanism of action of tumour necrosis factor- $\alpha$ and interleukin-1 on FRTL-5 rat thyroid cells. Acta Endocrinologica $1990123203-210$.

38 Westermark K, Nilsson M \& Karlsson FA. Effects of interleukin 1 alpha on porcine thyroid follicles in suspension culture. Acta Endocrinologica 1990122 505-512.

39 Nolte A, Bechtner G, Rafferzeder M \& Gartner R. Interleukin-1 $\beta$ (IL-1 $\beta$ ) binds to intact porcine thyroid follicles, decreases iodide uptake, but has no effect on cAMP formation or proliferation. Hormone and Metabolic Research 199426 413-418.

40 Weetman AP. Recombinant gamma-interferon stimulates iodide uptake and cyclic AMP production by FRTL-5 thyroid cell line. FEBS Letters 1987221 91-94.

41 Kraiem Z, Sobel E, Sadeh O, Kinarty A \& Lahat N. Effects of $\gamma$ interferon on DR antigen expression, growth, 3,5,3'-triiodothyronine secretion, iodide uptake, and cyclic adenosine $3^{\prime}, 5^{\prime}$ monophosphate accumulation in cultured human thyroid cells. Journal of Clinical Endocrinology and Metabolism 199071 817824 .

42 Sato K, Satoh T, Shizume K, Ozawa M, Han DC, Imamura H et al. Inhibition of ${ }^{125} \mathrm{I}$ organification and thyroid hormone release by interleukin-1, tumor necrosis factor- $\alpha$, and interferon- $\gamma$ in human thyrocytes in suspension culture. Journal of Clinical Endocrinology and Metabolism 199070 1735-1743.

43 Yamashita S, Kimura H, Ashizawa K, Nagayama Y, Hirayu H, Izumi $\mathrm{M}$ et al. Interleukin-1 inhibits thyrotrophin-induced human thyroglobulin gene expression. Journal of Endocrinology $1989122177-183$.

44 Krogh Rasmussen A, Feldt-Rasmussen U \& Bendtzen K. The effect of interleukin-1 on the thyroid gland. Autoimmunity 1993 16 141-148.

45 Krogh Rasmussen A, Kayser L, Feldt-Rasmussen U \& Bendtzen K. Influence of tumor necrosis factor- $\alpha$, tumor necrosis factor- $\beta$ and interferon-gamma, separately and added together with interleukin- $1 \beta$, on the function of cultured human thyroid cells. Journal of Endocrinology 1994143 359-365.

46 Poth M, Tseng YC \& Wartofsky L. Inhibition of TSH activation of human cultured thyroid cells by tumor necrosis factor: an explanation for decreased thyroid function in systemic illness. Thyroid 19911 235-240.

47 Krogh Rasmussen A, Kayser L, Feldt-Rasmussen U, Bech K, Bendtzen K, Diamant $M$ et al. Interleukin-6 is not a second mediator of interleukin-1 induced suppression of thyroid function in cultured human thyrocytes. Experimental and Clinical Endocrinology $199197179-181$.

48 Kung AWC \& Lau KS. Interferon- $\gamma$ inhibits thyrotropin-induced thyroglobulin gene transcription in cultured human thyrocytes. Journal of Clinical Endocrinology and Metabolism $1990701512-$ 1517.

49 Misaki T, Tramontano D \& Ingbar SH. Effects of rat gamma- and non-gamma-interferons on the expression of Ia antigen, growth, and differentiated functions of FRTL-5 cells. Endocrinology 1988 $1232849-2857$.

50 Nagayama Y, Izumi M, Ashizawa K, Kiriyama T, Yokoyama N, Morita $S$ et al. Inhibitory effect of interferon-gamma on the response of human thyrocytes to thyrotropin (TSH) stimulation: relationship between the response to TSH and the expression of DR antigen. Journal of Clinical Endocrinology and Metabolism 1987 64 949-953.

51 Ashizawa K, Yamashita S, Tobinaga T, Magayama Y, Kimura H, Hirayu $\mathrm{H}$ et al. Inhibition of human thyroid peroxidase gene expression by interleukin 1. Acta Endocrinologica $1989121465-$ 469.

52 Tominaga T, Yamashita S, Nagayama Y, Morita S, Yokoyama N, Izumi M et al. Interleukin 6 inhibits human thyroid peroxidase gene expression. Acta Endocrinologica 1991124 290-294.

53 Ashizawa K, Yamashita S, Nagayama Y, Kimura H, Hirayu H, Izumi $\mathrm{M}$ et al. Interferon- $\gamma$ inhibits thyrotropin-induced thyroidal peroxidase gene expression in cultured human thyrocytes. Journal of Clinical Endocrinology and Metabolism 198969 475477.

54 Asakawa H, Hanafusa T, Kobayashi T, Takai S-I, Kono N \& Tarui S. Interferon- $\gamma$ reduces the thyroid peroxidase content of cultured human thyrocytes and inhibits its increase induced by thyrotropin. Journal of Clinical Endocrinology and Metabolism 1992 74 1331-1335.

55 Yamazaki K, Yamada E, Kanaji Y, Shizume K, Wang D-S, Maruo $\mathrm{N}$ et al. Interleukin-6 (IL-6) inhibits thyroid function in the presence of soluble IL- 6 receptor in cultured human thyroid follicles. Endocrinology 1996137 4857-4863.

56 Zeki K, Azuma H, Suzuki H, Morimoto I \& Eto S. Effects of interleukin-1 on growth and adenosine $3^{\prime}, 5^{\prime}$-monophosphate generation of the rat thyroid cell line, FRTL-cells. Acta Endocrinologica 1991124 60-66.

57 Mine M, Tramontano D, Chin WW \& Ingbar SH. Interleukin-1 stimulates thyroid cell growth and increases the concentration of the c-myc proto-oncogene mRNA in thyroid follicular cells in culture. Endocrinology $19871201212-1214$.

58 Chen G, Pekary AE \& Hershman JM. Aging of FRTL-5 rat thyroid cells causes sensitivity to cytotoxicity induced by tumor necrosis factor- $\alpha$. Endocrinology $1992131863-870$.

59 Zakarija M, Horniceck FJ, Levis S \& McKenzie JM. Effects of gamma-interferon and tumor necrosis factor $\alpha$ on thyroid cells: induction of class II antigen and inhibition of growth stimulation. Molecular and Cellular Endocrinology 198858 129136.

60 Wassen FWJS, Moerings EPCM, van Toor H, De Vrey EA, Hennemann G \& Everts ME. Effects of interleukin-1 $\beta$ on thyrotropin secretion and thyroid hormone uptake in cultured rat anterior pituitary cells. Endocrinology $19961371591-1598$.

61 Kennedy JA, Wellby ML \& Zotti R. Effect of interleukin-1 $\beta$, tumour necrosis factor- $\alpha$ and interleukin- 6 on the control of thyrotropin secretion. Life Sciences 199557 487-501. 
62 Bernton EW, Beach JE, Holaday JW, Smallridge RC \& Fein HG Release of multiple hormones by direct action of interleukin-1 on pituitary cells. Science 1987238 519-521.

63 Bartalena L, Farsetti A, Flink IL \& Robbins J. Effects of interleukin-6 on the expression of thyroid hormone-binding protein genes in cultured human hepatoblastoma-derived (Hep G2) cells. Molecular Endocrinology 19922 313-323.

64 Bartalena L, Hammond GL, Farsetti A, Flink IL \& Robbins J. Interleukin-6 inhibits corticosteroid-binding globulin synthesis by human hepatoblastoma-derived (Hep G2) cells. Endocrinology $1993133291-295$.

65 Perlmutter DH, Dinarello CA, Punsal PI \& Colten HR. Cachectin/ tumor necrosis factor regulates hepatic acute-phase gene expression. Journal of Clinical Investigation 198678 1349-1354.

66 Ramadori G, van Damm J, Rider H \& Meyer K. Interleukin-6, the third mediator of acute phase reaction, modulates hepatic protein synthesis in human and mouse. Comparison with interleukin $1 \beta$ and tumour necrosis factor $\alpha$. European Journal of Immunology 198812 1259-1264.

67 Doherty GM, Lange JR, Langstein HN, Alexander HR, Buresh CM \& Norton JA. Evidence for IFN- $\gamma$ as a mediator of the lethality of endotoxin and tumor necrosis factor- $\alpha$. Journal of Immunology $19921491666-1670$.

68 Boelen A, Platvoet-ter Schiphorst MC, Bakker O \& Wiersinga WM. The role of cytokines in the lipopolysaccharide-induced sick euthyroid syndrome in mice. Journal of Endocrinology 1995146 475-483.

69 Boelen A, Maas MAW, Lowik CWGM, Platvoet-ter Schiphorst MC \& Wiersinga WM. Induced illness in interleukin-6 (IL-6) knockout mice: a causal role of IL- 6 in the development of the low 3,5,3'-triiodothyronine syndrome. Endocrinology 1996137 5250-5254.

70 Boelen A, Platvoet-ter Schiphorst MC \& Wiersinga WM. Immunoneutralization of IL-1, tumor necrosis factor, interleukin6 or interferon- $\gamma$ does not prevent the LPS-induced sick euthyroid syndrome in mice. Journal of Endocrinology 1997153 115-122.

71 Onoda N, Tsushima T, Isozaki O, Emoto N, Demura H, Arai M et al. Effect of interleukin- 6 on hypothalamic-pituitary-thyroid axis in rat. In: Eighty Years of Hashimoto Disease, pp 355-359. Eds S Nagataki, T Mori \& K Torizuka. Amsterdam: Elsevier Science, 1993.

72 Bartalena L, Grasso L, Brogioni S \& Martino E. Interleukin 6 effects on the pituitary-thyroid axis in the rat. European Journal of Endocrinology 1995131 302-306.

73 van Haasteren GAC, van der Meer MJM, Hermus ARMM, Linkels E, Klootwijk W, Kaptein E et al. Different effects of the continuous infusion of interleukin-1 and interleukin- 6 on the hypothalamichypophysial-thyroid axis. Endocrinology 1994135 1336-1345.

74 Lyson K \& McCann SM. The effect of interleukin-6 on pituitary hormone release in vivo and in vitro. Neuroendocrinology 1991 $54262-266$.

75 Dubuis JM, Dayer JM, Siegrist-Kaiser CA \& Burger AG. Human recombinant interleukin- $\beta$ decreases plasma thyroid hormone and thyroid stimulating hormone levels in rats. Endocrinology $19881232175-2181$.

76 Hermus ARMM, Sweep CGJ, van der Meer MJM, Ross HA, Smals AGH, Benraad TJ et al. Continuous infusion of interleukin-1 $\beta$ induces a nonthyroidal illness syndrome in the rat. Endocrinology $19921312139-2146$

77 Fujii T, Sato K, Ozawa M, Asono K, Imamura H, Kanaji Y et al. Effect of interleukin-1 (IL-1) on thyroid hormone metabolism in mice: stimulation by $\mathrm{IL}-1$ of iodothyronine $5^{\prime}$-deiodinating activity (type I) in the liver. Endocrinology 1989124 167-174.

78 Enomoto T, Sugawa H, Kosugi S, Inoue D, Mori T \& Imura H. Prolonged effects of recombinant interleukin- $1 \alpha$ on mouse thyroid function. Endocrinology 1990127 2322-2327.

79 Ozawa M, Sato K, Han DC, Kawakami M, Tsushima T \& Shizume K. Effects of tumor necrosis factor- $\alpha /$ cachectin on thyroid hormone metabolism in mice. Endocrinology 1988123 1461-1467.

80 Sweep CGJ, van der Meer MJM, Ross HA, Vranckx R, Visser TJ \& Hermus ARMM. Chronic infusion of TNF- $\alpha$ reduces plasma $\mathrm{T}_{4}$ binding without affecting pituitary-thyroid activity in rats. American Journal of Physiology 1992263 E1099-E1105.

81 Panciera DL, Helfand SC \& Soergel SA. Acute effects of continuous infusion of human recombinant interleukin-2 on serum thyroid hormone concentrations in dogs. Research in Veterinary Science 199558 96-97.

82 Mooradian AG, Reed RL, Osterweil D, Schiffman R \& Scuderi P. Decreased serum triiodothyronine is associated with increased concentrations of tumor necrosis factor. Journal of Clinical Endocrinology and Metabolism 199071 1239-1242.

83 Reincke M, Allolio B, Petzke F, Heppner C, Mbulamberi D, Vollmer $\mathrm{D}$ et al. Thyroid dysfunction in African trypanosomiasis: a possible role for inflammatory cytokines. Clinical Endocrinology $199339455-461$.

84 Chopra IJ, Sakane S \& Chua Teco GN. A study of the serum concentration of tumor necrosis factor- $\alpha$ in thyroidal and nonthyroidal illnesses. Journal of Clinical Endocrinology and Metabolism 199172 1113-1116.

85 Boelen A, Schiphorst Platvoet-ter MC \& Wiersinga WM. Association between serum interleukin-6 and 3,5,3'-triiodothyronine in nonthyroidal illness. Journal of Clinical Endocrinology and Metabolism 199377 1695-1699.

86 Bartalena L, Brogioni S, Grasso L, Velluzzi F \& Martino E. Relationship of the increased serum interleukin- 6 concentration to changes of thyroid function in nonthyroidal illness. Journal of Endocrinological Investigation 199417 269-274.

87 Bartalena L, Brogioni S, Grasso L \& Martino E. Interleukin-6 and the thyroid. European Journal of Endocrinology $1995132386-$ 393.

88 Hashimoto H, Igarashi N, Yachie A, Miyawaki T \& Sato T. The relationship between serum levels of interleukin- 6 and thyroid hormone in children with acute respiratory infection. Journal of Clinical Endocrinology and Metabolism 199478 288-291.

89 Amado JA, Lopez-Espadas F, Vàzquez-Barquero A, Salas E, Riancho JA, Lòpez-Cordovilla JJ et al. Blood levels of cytokines in brain-dead patients: relationship with circulating hormones and acute-phase reactants. Metabolism $199544812-816$.

90 Yokoe T, Iino Y, Takei H, Horiguchi J, Koibuchi Y, Maemura M et al. Changes of cytokines and thyroid function in patients with recurrent breast cancer. Anticancer Research 199717 695-697.

91 Murai H, Murakami S, Ishida K \& Sugawara M. Elevated serum interleukin- 6 and decreased thyroid hormone levels in postoperative patients and effects of IL- 6 on thyroid cell function in vitro. Thyroid 19966 601-606.

92 Saatvedt K \& Lindberg H. Depressed thyroid function following paediatric cardiopulmonary bypass: association with interleukin-6 release? Scandinavian Journal of Thoracic and Cardiovascular Surgery $19963061-64$.

93 Davies PH, Black EG, Sheppard MC \& Franklyn JA. Relationship between serum interleukin- 6 and thyroid hormone concentrations in 270 hospital in-patients with non-thyroidal illness. Clinical Endocrinology 199644 199-205.

94 Boelen A, Schiphorst Platvoet-ter MC \& Wiersinga WM. Relationship between 3,5,3'-triiodothyronine and serum interleukin-8, interleukin-10 or interferon- $\gamma$ in patients with nonthyroidal illness. Journal of Endocrinological Investigation $199619480-483$.

95 Boelen A, Schiphorst Platvoet-ter MC \& Wiersinga WM. Soluble cytokine receptors and the low 3,5,3'-triiodothyronine syndrome in patients with nonthyroidal disease. Journal of Clinical Endocrinology and Metabolism 199580 971-976.

96 van der Poll T, Romijn JA, Wiersinga WM \& Sauerwein HP. Tumor necrosis factor: a putative mediator of the sick euthyroid syndrome in man. Journal of Clinical Endocrinology and Metabolism 199071 1567-1572.

97 Schultz M, Muller R, Von zur Muhlen A \& Brabant G. Induction of hyperthyroidism by interferon-alpha. Lancet 1989 i 1452.

98 Fentiman IS, Thomas BS, Balkwill FR, Rubens RD \& Hayward JL. Primary hypothyroidism associated with interferon therapy of breast cancer. Lancet 1985 i 1166. 
99 Baudin E, Marcellini P, Pouteau M, Colas-Linhart N, Le Floch JP, Lemonnier $\mathrm{C}$ et al. Reversibility of thyroid dysfunction induced by recombinant alpha interferon in chronic hepatitis C. Clinical Endocrinology $199339657-661$.

100 Corssmit EPM, Heylingenberg R, Endert E, Sauerwein HP \& Romijn JA. Acute effects of interferon- $\alpha$ administration on thyroid hormone metabolism in healthy men. Journal of Clinical Endocrinology and Metabolism 199580 3140-3144.

101 Stouthard JML, van der Poll T, Endert E, Bakker PJM, Veenhof CHN, Sauerwein HP et al. Effects of acute and chronic interleukin-6 administration on thyroid hormone metabolism in humans. Journal of Clinical Endocrinology and Metabolism 1994 79 1342-1346.

102 van der Poll T, van Zee KJ, Endert E, Coyle SM, Stiles DM, Pribble JP et al. Interleukin-1 receptor blockade does not affect endotoxin-induced changes in plasma thyroid hormone and thyrotropin concentrations in man. Journal of Clinical Endocrinology and Metabolism 199580 1341-1346.

103 Cannon JG, Tompkins RG \& Gelfand JA. Circulating interleukin-1 and tumor necrosis factor in septic shock and experimenta endotoxin fever. Journal of Infectious Diseases 1990161 79-84.

104 Fong Y, Marano MA \& Moldawer LL. The acute splanchnic and peripheral tissue metabolic response to endotoxin in humans. Journal of Clinical Investigation 199085 1896-1904.

105 Mattijssen WJM, De Mulder PHM, Van Liessun PA, Corstens FHM, Franks CR \& Wagener DJT. Hypothyroidism and goitre in a patient during treatment with interleukin-2. Cancer 199065 2686-2688.

106 Schwartentruber DJ, White DE, Zweig MH, Weintraub BD \& Rosenberg SA. Thyroid dysfunction associated with immunotherapy for patients with cancer. Cancer 199168 23842390.

107 Vialettes B, Guillerand MA, Viens P, Stoppa A-M, Baume D, Sauvan $\mathrm{R}$ et al. Incidence rate and risk factors for thyroid dysfunction during recombinant interleukin-2 therapy in advanced malignancies. Acta Endocrinologica 1993129 31-38.

108 Kung AWC, Lau CL, Wong KL \& Tam CF. Thyroid function in patients treated with interleukin-2 and lymphokine-activated killer cells. Quarterly Journal of Medicine 1991297 33-42.

109 Bartalena L, Marcocci C \& Pinchera A. Cytokine antagonists: new ideas for the management of Graves' ophthalmopathy. Journal of Clinical Endocrinology and Metabolism 199681 446448 .

110 DeGroot LJ, Larsen PR \& Hennemann G. The Thyroid and its Diseases, edn 6, p 171. New York: Churchill Livingstone, 1996.

111 Klemperer JD, Klein I, Gomez M, Helm RE, Ojamaa K, Thomas SJ et al. Thyroid hormone treatment after coronary-artery bypass surgery. New England Journal of Medicine 1995333 1522-1527.

Received 13 November 1997

Accepted 5 February 1998 